\title{
El anti-don Juan de Valle-Inclán, García Márquez y Mayra Montero en las Sonatas, Memoria de mis putas tristes y Púrpura profundo
}

\author{
William O. Deaver ${ }^{1}$
}

This article explores and analyzes the treatment of the anti-don Juan in the Sonatas of Ramón del Valle-Inclán, Memoria de mis putas tristes by Gabriel García Márquez, and Púrpura profundo by Mayra Montero. Each of the novels presents an old, decrepit don Juan on the brink of death whose memories seem distorted and hyperbolic exaggerations of how they would have liked to live, rather than how they actually lived. As such, their memories are examples of a blurry line between erotica and pornography. Music is the key leitmotif that gives each novel a structural unity, but these works seem to be more of a funeral dirge than a celebration of life. [Article copies available for a fee from The Transformative Studies Institute. E-mail address: journal@transformativestudies.org Website: http://www.transformativestudies.org (C2018 by The Transformative Studies Institute. All rights reserved.]

KEYWORDS: Valle-Inclán, García Márquez, Montero, Music, Erotica, don Juan.

Don Juan se destaca entre los personajes de la literatura castellana. Mayormente, es joven, guapo, irreligioso, y amoral si no inmoral. Además, es un atrevido oportunista que infringe los límites sociales tanto como morales al seducir, asesinar y blasfemar en su afán hedonista. Ramón del Valle-Inclán lo invierte cuando retrata al Marqués de Bradomín como "[. . .] el más admirable de los Don Juanes: Feo, católico y sentimental" (Invierno 172). Intrínsecamente, el don Juan no es admirable, sino despreciable. Como Valle-Inclán anteriormente, Mayra Montero y Gabriel García Márquez exploran la idea de un don Juan decrépito y moribundo cuyas memorias sirven como confesión y canto fúnebre-un réquiem-en lugar de una jactancia que celebra sus

\footnotetext{
${ }^{1}$ William O. Deaver, Jr. Ph.D., is a professor of Spanish at Armstrong State University. He holds a BA in English and an MA in Spanish from the University of Virginia. He holds a Ph.D. in Spanish from Florida State University. He has published on authors from Spain, Latin America, and on Hispanic authors of the U.S. Address correspondence to: Dr. William O. Deaver, Armstrong State University, Savannah, Georgia 31419; e-mail: bill.deaver@armstrong.edu.
} 